研究課題別評価

1 研究課題名:

有糸分裂チェックポイント遺伝子 CHFR のがん診断·治療への応用

2 研究者氏名:

豊田 実

3 研究のねらい:

細胞周期のチェックポイントは細胞に様々なストレスが加えられた際、細胞がストレスに対応す るため、細胞周期を停止させ、問題を修復することに重要である。がんにおいては、しばしば細胞 周期のチェックポイントに関与する遺伝子に異常が起き、その分子機構について報告されてきた。 われわれは、これまで報告が少ない有糸分裂期チェックポイントに関連するCHFRについて、がん における異常メチル化によるサイレンシングについて報告した(Proc Natl Acad Sci USA, 2003)。 CHFR は ring finger domain を有する、ユビキチンリガーゼで、G2 期から分裂期への途中 prophase において、微小管ストレスがあった際、核膜が崩壊するか否かのチェックポイントに関与する。し かし、チェックポイントの分子機構や生理的役割、ユビキチンの基質などについては未知の点が 多い。本研究では、CHFR による分裂期チェックポイントの分子機構を明らかにし、がんにおける 微小管阻害剂感受性予測への応用や、分子標的としての可能性について検討する。また、CHFR 不活化の機構として、DNA メチル化を有するがんの特徵を明らかにする。さらに、ノックアウトマウ スの作成による、個体における機能解析や発がんにおける役割の解析を行う。

4 研究成果:

1). CHFR 遺伝子の異常メチル化を指標とした微小管阻害剂感受性の予測およびがん診断 CHFR が異常メチル化を示すがん細胞株は、微小管阻害剂処理により、Cyclin B1 の核への蓄積、 Histone H3ser10 のリン酸化、核の凝集など Prophase チェックポイントの異常を示した。CHFR が 異常メチル化を示すがん細胞株は、 paclitaxel や docetaxelなどの微小管阻害剤により誘導される アポトーシスに高い感受性を示した。ロ腔扁平上皮がん臨床例の術前化学療法においても、 CHFR の異常メチル化は、docetaxel によるネオアジュバント治療の感受性予測に有用と考えられ た。CHFR が正常に機能している腫瘍細胞は微小管阻害剤投与により、G2 期に停止してしまい、 薬剤抵抗性を示す。そこでわれわれは、CHFR をノックダウンすることにより、微小管阻害剂の作 用を増強出来るか検討した。CHFR ノックダウンするための shRNA ベクタ一を作成し、CHFR が発 現している細胞株に導入したところ、微小管阻害剤処理による mitotic index の増加や薬剤感受性 の増強を認めた(図1)。これらの結果より、CHFR は微小管阻害剂の感受性を増強する重要な分 子標的亡考えられた。また、CHFR の異常メチル化は、便や胃液、膵液、胆汁液からも検出可能で あり、がんの分子マーカーとして有用である可能性が示唆された。大腸がんや胃がん以外でも、 口腔扁平上皮がん、成人 $\mathrm{T}$ 細胞性白血病において、CHFR の異常メチル化による発現消失を認 め、その不活化は幅広い腫瘍において重要であることが示唆された。

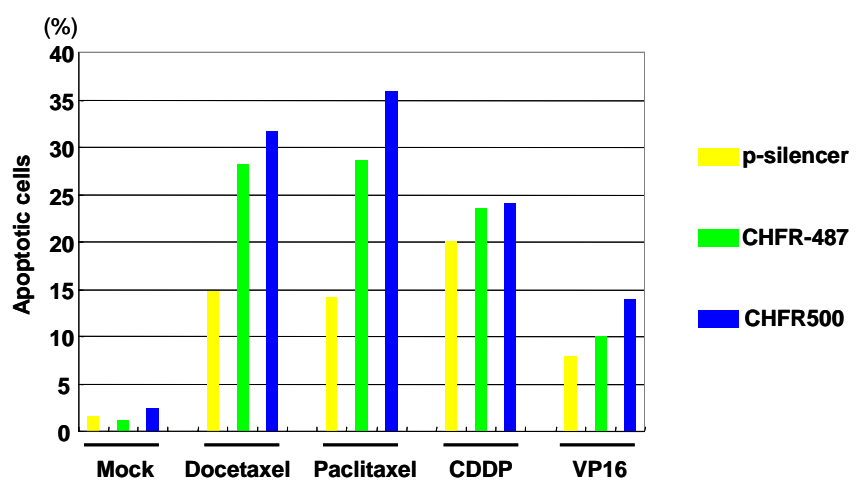


図1.CHFR のノックダウンにより微小管阻害剤、docetaxel、Paclitaxel に対する薬剤感 受性が増強した。

2). CHFR 遺伝子の異常メチル化と CpG island methylator phenotype、EB ウイルス

CHFR がメチル化している腫瘍の特色を明らかにする目的で、CHFR 以外の遺伝子のジェネティッ クあるいはエピジェネティックな異常の解析を行った。大腸がんや胃がんにおいては、CHFR の異 常メチル化は、ゲノムワイドな異常メチル化、 CpG island methylator phenotype (CIMP)を示す腫瘍 に特異的に認められた(図2)。これらの腫瘍は、K-ras あるいは BRAF 遺伝子の異常が非常に高 率で、p53 の遺伝子変異をほとんど有しない、などの特徵を有した。胃癌においては、 Epstein-Barr ウイルス陽性の胃がんにおいてCHFRのメチル化を高率に認めた。以上の結果から、 異常メチル化はランダムに起きているのではなく、メチル化の制御機構に異常を有する腫瘍に特 異的に起こっている可能性が示唆された。

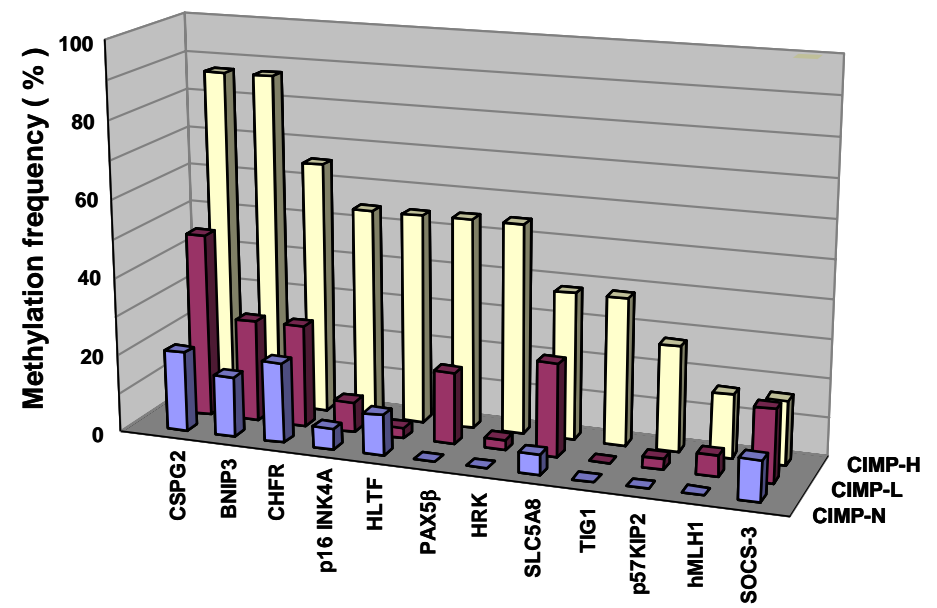

図2. CHFR の異常メチル化は、ゲノムワイドな異常メチル化、CpG island methylator phenotype (CIMP)を有する腫瘍で高率に認められる。

3). CHFR と相互作用する分子の解析

CHFR の機能を明らかにする目的で、Two hybrid screening 法あるいは、Flag-CHFR を遺伝子導 入した細胞において、抗 Flag 抗体で免疫沈降される分子をマススペクトメトリーによって解析し、 CHFR と相互作用する分子の同定を試みた。その結果、PARP1、TAB2 が CHFR と相互作用する 分子として同定された。PARP1 は CHFR がメチル化している大腸がん細胞株 HCT116にCHFRを 遺伝子導入すると、PARP1 はュビキチン化を認め、CHFR の新しい基質と考えられた。また、 PARP1 は微小管ストレスの際、Ku80 と相互作用することを明らかにした。また、CHFR が DNA メ チル化により不活化されている腫瘍細胞において、PARP1 の発現が上昇していることを見出し た。

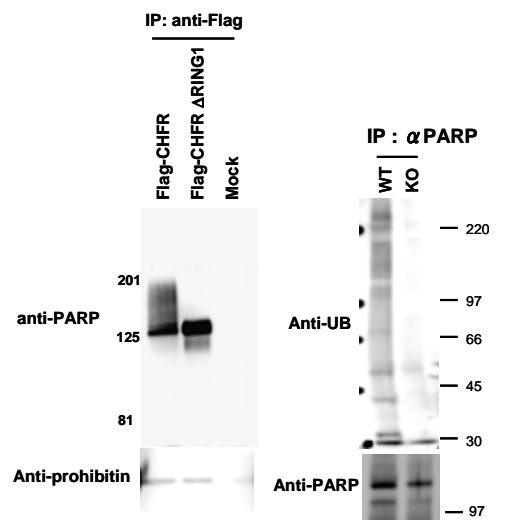

図3. CHFR によるPARP1 のユビキチン化 
4). CHFR が関与するシグナル伝達経路の解析

CHFRが関与するシグナル伝達経路の解析する目的で、 adenovirus vectorによりCHFRを遺伝子 導入し、発現が変動する遺伝子に関して、cDNA microarray による網羅的解析を行った。CHFR の 遺伝子導入により、IL-8 をはじめとする NF-kB の標的遺伝子の発現が抑制されており、CHFR が NF-kB を抑制する可能性が示唆された。また、CHFR により発現が抑制される遺伝子群には、 Jun を始めとする MAPK 経路の下流遺伝子が多数存在し、CHFR による微小管ストレス応答に MAPK 経路の抑制が関与する可能性が示唆された。ルシフェラーゼアッセイにより、CHFR を HCT116 細胞に遺伝子導入するとNF-kB の転写活性が抑制されることが明らかとなった。また、こ の転写抑制は ring fingerドメインを欠く変異体にも認められ、CHFR が E3 活性非依存的に NF-kB を抑制していることが示唆された。クロマチン免疫沈降法により、CHFR による、IL-8 の発現抑制 には、p65 のプロモーターへの結合が阻害されていることが関与すると考えられた。

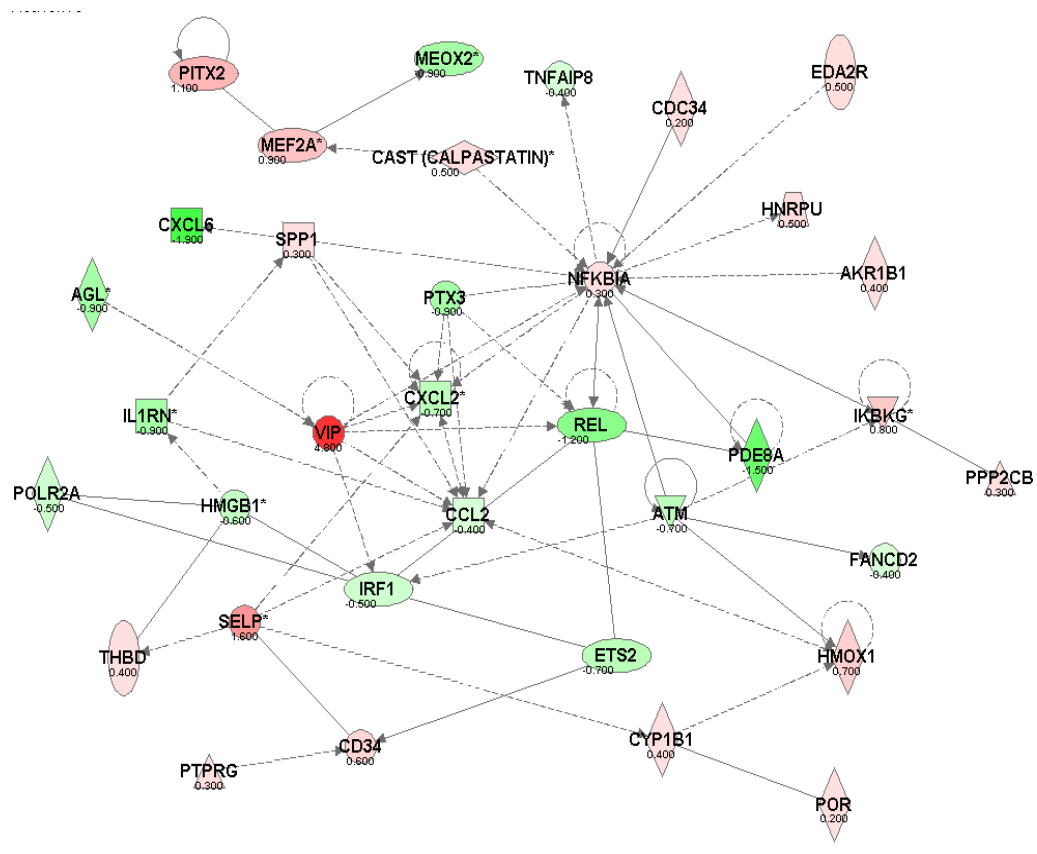

図4. CHFR の遺伝子導入により発現が上昇(赤字)あるいは減少した遺伝子(緑字)と NF-kB 経路 CHFR 導入により発現が変動した遺伝子をマイクロアレイで解析し、Ingenuity softwareにて可視化した。

5). CHFR ハックアウトマウスの作成

CHFR-/ーマウスは正常に発生し、CHFR は個体の発生には必須でないことが示唆された。 CHFR-/ーマウス由来の MEF は、docetaxel 処理により、8n 細胞の出現、アポトーシスの増強を認 めた。CHFR が染色体の安定性の維持に重要であることが示唆された。CHFR ノックアウトマウス を作製し、バッククロスにより、C57B6 のバックグラウンドを持ったヘテロ欠失マウスを作製中であ る。 


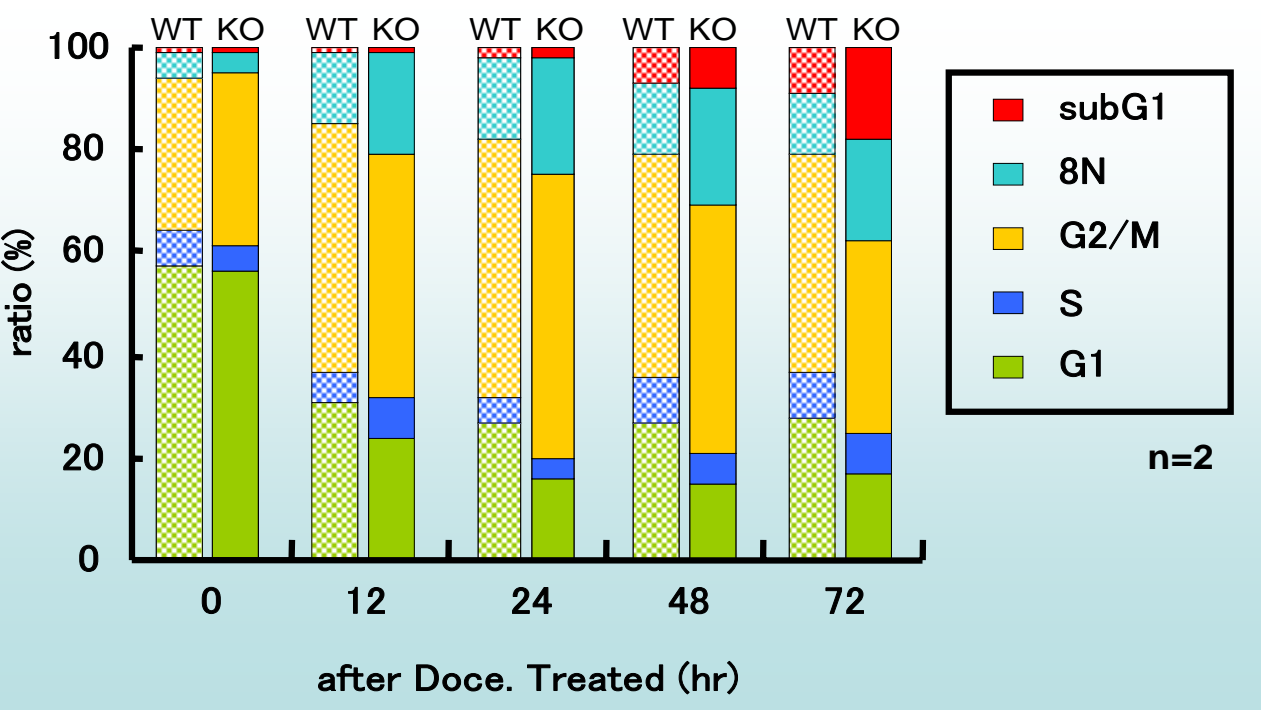

図5. CHFR ノックアウトマウス由来の MEF(KO)は、decetaxel 処理により、8N および subG1 分核の細胞が WT マウス由来 MEF(WT)に比べ優位に多い。

\section{5 自己評価:}

当初目標とした、CHFR のメチル化をマーカーとした、微小管阻害剂に対する感受性予測や、 CHFR の発現抑制による、微小管阻害剂の感受性の増強に関しては、一定の成果を上げたと思う。 遺伝子メチル化解析に関しては、CHFR がメチル化している大腸がんや胃がんの分子異常を網羅 的に解析し、メチル化陽性腫瘍の特徵を明らかにした。ここまでは、比較的予想通りの結果であっ た。今後異常メチル化がなぜ起こるのかについて、前がん病変における解析やモデル動物を用い た解析を詳細に行いたい。また、最近では、DNA メチル化に、RNA 依存性遺伝子サイレンシング が関与する可能性も見出し、今後さらに研究を進める予定である。

一方、生化学的解析や個体を用いた解析は、研究期間内に終了出来なかったものが多く、今 後の課題である。CHFR が NF-kB の経路に関与することは予想外であったが、がん抑制遺伝子と しての機能や、炎症への関与を考えると興味深い。NF-kB 抑制における、CHFR の作用点をピン ポイントで抑えることができておらず、これも今後の課題である。今後、ノックアウトマウスを用いた 個体レベルでの解析により、炎症や癌の感受性にCHFR 欠損がどのような役割を果たしているか、 疾患との関連を重点に明らかにしていきたい。

\section{6 研究総括の見解:}

有糸分裂チェックポイントで機能する CHFR に関して、遺伝子 CpG アイランドの異常メチル化を 中心に、相互作用をする分子、シグナル伝達経路などいくつかの方向から解析し、しかるべき結 果を出していて評価できる。このさきがけ研究では CHFR 遺伝子のメチル化解析が独自性の発揮 ポイントであり、その方向でいかにがんに迫るかが期待されたので、他でもやりそうな機能解析に 広がってしまったことに少々物足りなさを感じる。結果としての CHFR 遺伝子の異常メチル化であ ったとしても、その細胞ではなぜ異常メチル化が起こるのかの本源に切り込むことが重要と考えら れ、今後の研究発展が期待される。

\section{7 主な論文等:}

\section{原著論文}

1. Suzuki H, Watkins DN, Jair KW, Schuebel KE, Markowitz SD, Chen WD, Pretlow TP, Yang B, Akiyama Y, Van Engeland M, Toyota M, Tokino T, Hinoda Y, Imai K, Herman JG, Baylin SB. Epigenetic inactivation of SFRP's complements genetic alterations to allow constitutive Wnt 
pathway signaling in human colorectal cancer. Nat Genet, 36: 417-422, 2004.

2. Ogi K, Toyota M, Mita H, Satoh A, Kashima L, Sasaki Y, Suzuki H, Akino K, Noguchi M, Shinomura $Y$, Imai K, Hiratsuka $H$ and Tokino T. Small interfering RNA-induced CHFR silencing sensitizes oral squamous cell cancer cells to microtubule inhibitors. Cancer Biol. Ther. 4: 773-780, 2005.

3. Akino K, Toyota M, Suzuki H, Mita H, Sasaki Y, Ohe-Toyota M, Issa JP, Hinoda Y, Imai K, Tokino T. The RAS effector RASSF2 is a novel tumor suppressor in colorectal cancer. Gastroenterol, 129: 156-169, 2005.

4. Kusano M, Toyota M, Suzuki H, Akino K, Aoki F, Fujita M, Hosokawa M, Shinomura Y, Imai K, Tokino T. Genetic, epigenetic and clinicopathological features of gastric cancers with $\mathrm{CpG}$ island methylator phenotype and an association with Epstein-Barr virus. Cancer, 106, 1467-1479, 2006.

5. Maruyama R, Aoki F, Toyota M, Sasaki Y, Akashi H, Mita H, Suzuki H, Akino K, Ohe-Toyota M, Maruyama $\mathrm{Y}$, Tatsumi H, Imai K, Shinomura $\mathrm{Y}$, Tokino T. Comparative genome analysis identified the vitamin $\mathrm{D}$ receptor gene as a direct target of p53-mediated transcriptional activation. Cancer Res, 66: 4574-4583.2006.

他に論文 14 件(国際)、総説 11 件(国際 4 件、国内 7 件)、口頭発表 15 件(国際 4 件、国内 11 件)

特許出願: 国内 3 件

受賞:なし

招待講演:なし 